\title{
Erratum to: Toxicological effects of the sunscreen UV filter, benzophenone-2, on planulae and in vitro cells of the coral, Stylophora pistillata
}

\author{
C. A. Downs - Esti Kramarsky-Winter · John E. Fauth - Roee Segal • \\ Omri Bronstein - Rina Jeger · Yona Lichtenfeld · Cheryl M. Woodley • \\ Paul Pennington $\cdot$ Ariel Kushmaro $\cdot$ Yossi Loya
}

Published online: 15 March 2014

(c) Springer Science+Business Media New York 2014

\section{Erratum to: Ecotoxicology (2014) 23:175-191 \\ DOI 10.1007/s10646-013-1161-y}

The units mentioned in the texts and figures were incorrect in the original publication which have been corrected in this erratum.

In the Abstract section, the last two sentences should read as "The LC50 of BP-2 in the light for an 8 and 24 hour exposure was 120 parts per million (ppm) and 165 parts per billion (ppb), respectively. The LC50s for BP-2 in darkness for the same time points were 144 parts per million and 548 parts per billion."

The online version of the original article can be found under doi:10. 1007/s10646-013-1161-y.

C. A. Downs $(\square)$

Haereticus Environmental Laboratory, P.O. Box 92, Clifford,

VA 24533, USA

e-mail: cadowns@haereticus-lab.org

E. Kramarsky-Winter · R. Segal · O. Bronstein · Y. Loya Department of Zoology, George S. Wise Faculty of Life Sciences, Tel Aviv University, 69978 Tel Aviv, Israel

E. Kramarsky-Winter · Y. Lichtenfeld · A. Kushmaro Avram and Stella Goldstein-Goren Department of Biotechnology Engineering, Faculty of Engineering Sciences and National Institute For Biotechnology in the Negev, BenGurion University of the Negev, 84105 Beer Sheva, Israel

\section{J. E. Fauth}

Department of Biology, University of Central Florida, 4000 Central Florida Boulevard, Orlando, FL 32816-2368, USA

\section{R. Jeger}

Department of Life Sciences, Ben-Gurion University of the Negev, 84105 Beer Sheva, Israel
Under "Materials and methods" section, the last sentence in the 3rd paragraph should read as " $1 \mathrm{mM}$ BP-2 (246 ppm), 0.1 mM BP-2 (24.6 ppm), $0.01 \mathrm{mM} \mathrm{BP-2} \mathrm{(2.46}$ ppm), $0.001 \mathrm{mM}$ BP-2 (246 ppb), $0.0001 \mathrm{mM}$ (24.6 ppb), and $0.00001 \mathrm{mM}(2.46 \mathrm{ppb}) . "$

In the Figure Legend 1, it currently reads, " $24.6 \mathrm{ppm}$ BP-2 for $8 \mathrm{~h}$ in the light". It should be "24.6 ppb BP-2 for $8 \mathrm{~h}$ in the light"

Under the section " $\mathrm{LC}_{50}, \mathrm{EC}_{20}$ and $\mathrm{EC}_{50}$ ", the last two sentences in the second paragraph should read as "Nonlinear regression estimation of DNA AP abasic sites $\mathrm{EC}_{20}$ and $\mathrm{EC}_{50}$ for $\mathrm{BP}-2$ in the light are 52 pptrillion $(0.211 \mathrm{nM})$ and $8.6 \mathrm{ppb}(34.9 \mathrm{nM})$, respectively. Non-linear regression estimation of DNA AP abasic sites $\mathrm{EC}_{20}$ and $\mathrm{EC}_{50}$ for BP-2 in the dark are four pptrillion $(0.016 \mathrm{nM})$ and $1.8 \mathrm{ppb}(7.12$ $\mathrm{nM})$, respectively."

C. M. Woodley

Hollings Marine Laboratory, U.S. National Oceanic \& Atmospheric Administration, 331 Ft. Johnson Rd., Charleston, SC 29412, USA

C. M. Woodley · P. Pennington

Center for Coastal Environmental Health and Biomolecular Research, U.S. National Oceanic \& Atmospheric Administration, 219 Ft. Johnson Rd., Charleston, SC 29412, USA

A. Kushmaro

School of Materials Science \& Engineering, Nanyang

Technological University, 50 Nanyang Avenue,

Singapore 639798, Singapore 
In the Figure Legend 4, it currently reads, “...exposed to $246 \mathrm{ppm}$ benzophenone- 2 for $8 \mathrm{~h}$ in the light. It should be " 246 ppb (parts per billion)

Below Figure 4, the last sentence in the first paragraph should read as, "The corresponding EC20s were very low: 246 pptrillion $(1 \mathrm{nM})$ for planulae exposed in the light and $9.6 \mathrm{ppb}(39 \mathrm{nM})$ for planulae exposed to BP-2 for 24 hours in the dark."
In the Figure Legend 5, it currently reads, “...exposed to $246 \mathrm{ppm}$ benzophenone- 2 for $8 \mathrm{~h}$ in the dark. It should be " $246 \mathrm{ppb}$ (parts per billion)

Below Figure 5, the first equation should read as, "In the light $\left(\mathrm{F}_{2,21}=26.2, P<0.0001, \mathrm{R}^{2}=0.71\right)$ " 